\title{
Economic Integration of Immigrant Entrepreneurs
}

\author{
Nonna Kushnirovich
}

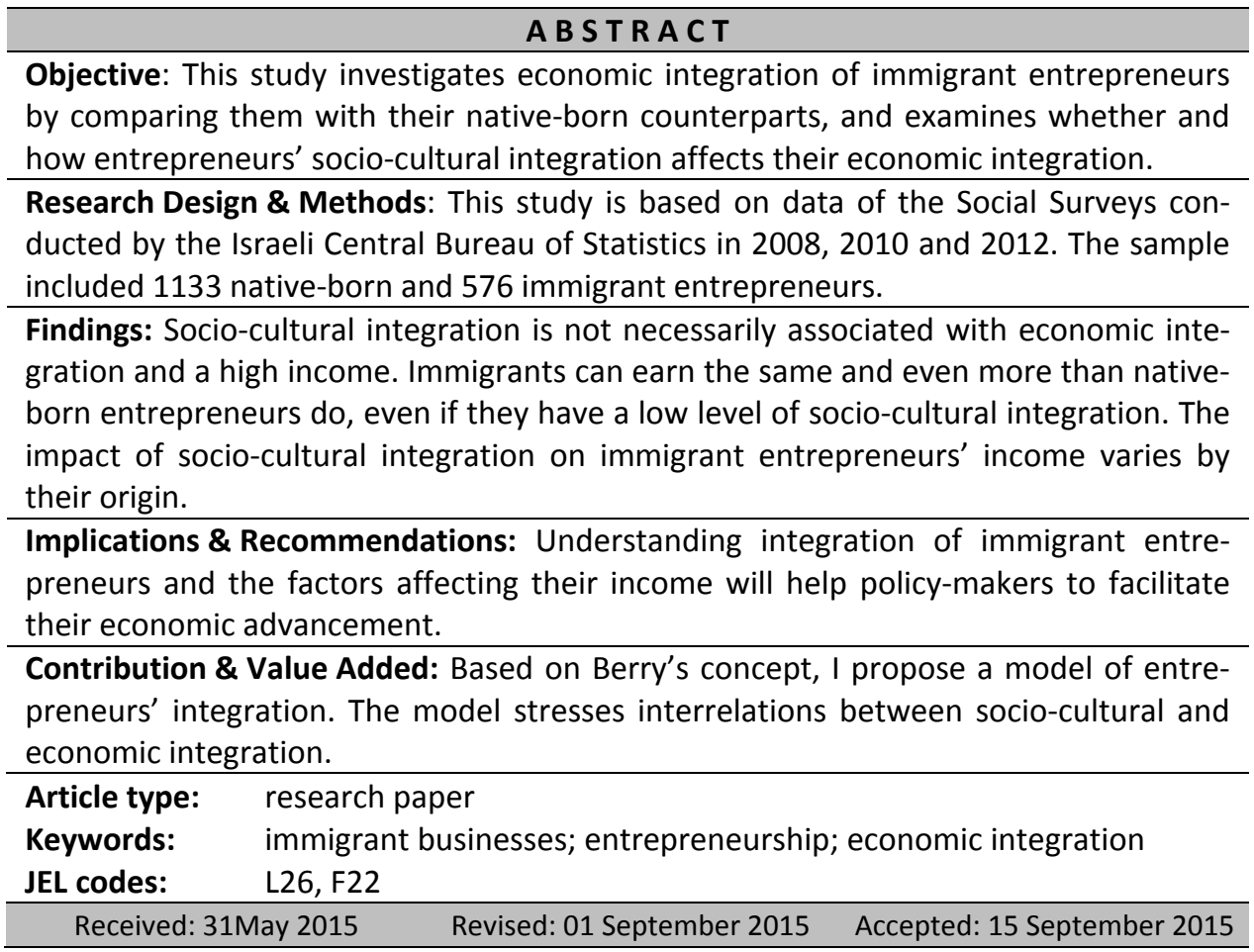

\section{Suggested citation:}

Kushnirovich, N. (2015). Economic Integration of Immigrant Entrepreneurs. Entrepreneurial Business and Economics Review,3(3), 9-27. doi: 10.15678/EBER.2015.030302 


\section{INTRODUCTION}

In business and immigrant research, the issue of immigrant entrepreneurship is recently in the limelight. Immigrant entrepreneurship is considered a viable employment and income solution for immigrants, a bypass option for economic advancement, and an important factor of immigrants' integration in the host country (Heilbrunn \& Kushnirovich, 2008; Riva \& Lucchini, 2015). Income is commonly considered a sign of immigrants' economic integration; therefore, investigating income of entrepreneurs is of great importance.

Whereas the issue of economic integration and earnings of salaried immigrant workers is widely discussed in the literature (see Borjas, 1994; Chiswick; 1978; Cohen \& Haberfeld, 2007; Constant \& Zimmermann, 2009), there is a paucity of studies on economic integration of entrepreneurs. Most studies on immigrant entrepreneurs focus on their socio-cultural integration in terms of involvement in co-ethnic dealing within immigrant ethnic enclaves (Barrett et al., 2002; Kloosterman \& Rath, 2001; Portes \& Jensen, 1992; Sanders \& Nee, 1992; Wilson \& Martin, 1982). Some scholars claim that co-ethnic dealing does not provide entrepreneurs with higher benefits, and they are even penalized economically (Aguilera, 2009; Bates, 1996; Ndofor \& Priem, 2011). Other scholars posit that utilizing ethnic networks helps to mobilize capital, recruit cheap labor, gain clients and suppliers, access information, and, in this way, facilitate sales and income generation (Danes et al., 2008; Dyer, 2006; Ibrahim \& Galt, 2011). According to these contradicting approaches, the questions whether immigrant entrepreneurs earn more or less than their native-born counterparts, and whether socio-cultural integration of immigrant entrepreneurs is a necessary condition for their economic integration, remain open.

This paper aims to fill this gap by investigating economic integration of immigrant entrepreneurs in terms of their incomes, and understanding how socio-cultural integration relates to economic integration, and what the ethnic differences in their relationship are. This study contributes to research on entrepreneurship, but also to migration research by developing a model of entrepreneurs' integration based on Berry's (1997) concept.

The study focuses on immigrant and native-born entrepreneurs in Israel. By examining the data of the annual 2008, 2010 and 2012 national Social Surveys, and applying ordinal regression techniques, the study demonstrates that being an immigrant does not mean automatically receiving lower income, and that immigrants' integration differs between immigrant groups.

The plan of this paper is as follows: the first part of the paper reviews the relevant literature and is devoted to theoretical approaches to economic and socio-cultural integration of immigrant entrepreneurs and determinants of such integration; the next part presents the study's empirical model specification, data source, and measures. The third part illustrates the results of the study. It is devoted to differences in income between various groups of immigrant and native-born entrepreneurs, and investigates the relationship between socio-cultural integration and income controlling for personal and business characteristics. The final section summarizes the findings and discusses the conclusions. 


\section{LITERATURE REVIEWAND THEORY DEVELOPMENT}

A growing range of studies on immigrant entrepreneurship characterizes immigrant businesses as relatively small, low-income ventures (Ensign \& Robinson, 2011; Neville et al., 2014). Entrepreneurs' low income is often explained by their orientation toward coethnic immigrant communities. Immigrant clients tend to buy cheaper goods that can reduce revenue of immigrant businesses. Reliance on co-ethnic markets can constrain market penetration and growth of business since its potential for sustainable economic growth is limited by the size of such market (Curci \& Mackoy, 2010; Danes et al., 2008; Ibrahim \& Galt, 2011).

Nevertheless, empirical studies on immigrant business performance demonstrated mixed results. When most studies found that immigrant businesses perform worse than those owned by native-born persons, and the incomes of immigrant entrepreneurs are lower (Baycan-Levent \& Nijkamp, 2009; Ndofor \&Priem, 2011; Heilbrunn \& Kushnirovich, 2007), other authors found no discernible income differences between self-employed natives and immigrants (Constant \& Zimmermann, 2006). They claim that immigrant business outcomes vary by the origin and ethnicity of the owner (Robb \& Fairlie, 2009; Riva \& Lucchini, 2015), and that self-employed immigrants of certain origin can have even higher incomes than comparable self-employed natives do (Borjas, 1994; Robb \& Fairlie, 2009). Irrespective of the position as to existing income gaps between immigrant and native-born entrepreneurs, there is a common consensus in the literature that the income of immigrant businesses and immigrant entrepreneurs tends to increase with the years of exposure to the host country. This rise is often explained as a result and a sign of immigrants' integration (Amit, 2012; Bommes \& Kolb, 2006; Chiswick \& Repetto, 2000; Constant \& Zimmermann, 2009; Lofstrom, 2004).

In the literature, two kinds of immigrants' integration are discussed: socio-cultural integration and economic integration. Socio-cultural integration is usually analyzed in the framework of Berry's model of acculturation (Berry, 1997, 2003, 2005). According to this model, integration is one of four acculturation strategies: Assimilation, Integration, Separation, and Marginalization. If immigrants retain both their culture of origin and adopt the host society culture, they are considered as integrated in the host society. When they replace the patterns of their culture of origin with those of the host society, they adopt assimilation. If they avoid interaction with the host society while keeping their culture of origin, this strategy is called separation, and marginalization occurs when immigrants neither maintain their culture of origin nor interact with the host society (Berry, 1997, 2003, 2005).

The extent of involvement in the culture of the host country is usually described in terms of host country language skills and the length of exposure to this culture. Language proficiency is a central and unique factor reflecting immigrants' integration (Amit, 2012). Language is one of five core elements chosen by Constant, Gataullina \& Zimmermann (2009) for evaluating ethnic identity and calculating a so-called ethnosizer index of cultural and societal commitment, which quantifies how ethnic an individual is. Immigrants who are better skilled in the language of the host country and speak it on a daily basis are more integrated into the mainstream economy (Chiswick \& Repetto, 2000); correspondingly, they earn more than those who have a language barrier (Constant \& Zim- 
mermann, 2006). Immigrants weaker in language skills have fewer social or business links with the native community, that restricts their opportunity scope and thus influences their business activity (Stone \& Stubbs, 2007). Owners of ethnic businesses do not have to study the language of the host country; they can communicate with clients, workers, and suppliers in their mother language (Aguilera, 2009; Ibrahim \& Galt, 2011; Olson, Zuiker \& Montalto, 2000). This is a strategy of separation or marginalization, but not of integration.

Interaction of immigrants with the culture of the host country and the extent of their involvement in it should be greater the longer immigrants are exposed to it. Exposure in time units is usually measured by length of residence in the host country, in other words, years that have passed since migration (Chiswick \& Repetto, 2000; Amit, 2012). The years of exposure to the host country is a crucial element of immigrants' socio-cultural integration. This is relevant for immigrant entrepreneurs even more than for salaried workers, since setting up and operating a business requires intensive contacts and communication with the native population and native-born representatives of institutions (authorities, banks etc.). This communication requires adopting the social norms of the host country. Thus, socio-cultural integration of entrepreneurs can be described in terms of host country language skills and length of residence in the host country, by which each parameter has an independent effect on the immigrants' income (Algan et al., 2010; Dustmann, 2000).

Whereas there is consensus among social scientists regarding the strategies of sociocultural integration, economic studies often do not distinguish between the concepts of assimilation and integration. Economic integration is generally discussed in terms of earnings parity between immigrants and natives with similar characteristics (Amit, 2012; Cohen \& Haberfeld, 2007), and a rise of immigrants' income over time (Borjas, 1994). According to Chiswick (1978), assimilation is the rate at which the earnings of immigrants converge to or even exceed the earnings of the native population. Constant \& Zimmermann (2009) posit that 'catching up of earnings' means that immigrants and natives are indistinguishable in terms of their earnings, and economic assimilation is achieved. According to Bommes \& Kolb (2006), when assimilation strategy occurs, immigrant entrepreneurs adopt the entrepreneurial principles of the native population. Their study is one of the rare ones, which distinguish between economic assimilation and integration of entrepreneurs. They define the latter as the "ability to pay and the effort to gain this ability by either selling services or goods" (Bommes \& Kolb, 2006, p. 100).

Research on entrepreneurship has proposed that business outcomes are affected by factors concerning the individual, firm, and environment (context) (Santarelli \& Vivarelli, 2007; Storey, 1994). Human, social, and economic capital of entrepreneurs are crucial factors of business success (Lerner \& Khavul, 2003). Personal characteristics and education of business owners, as well as firm characteristics, explain variation in business outcomes across entrepreneurs of different origin (Riva \& Lucchini, 2015).

The role of personal characteristics and education in immigrant entrepreneurship is widely discussed in the literature. Education usually is considered as a factor that positively affects success of immigrant entrepreneurs in terms of their earnings (Robinson \& Sexton, 1994). Age is another important determinant of income. The earnings of immigrant entrepreneurs increase with age (Fairlie, 2004; Lofstrom, 2004), when the rates of 
their growth decrease (Constant \& Shachmurove, 2006) However, some authors posit that young immigrant entrepreneurs, who have socialized in the host country and have better language proficiency, earn more than their native-born counterparts do (Constant \& Schulz-Nielsen, 2004). Another personal characteristic that is likely to affect the income of immigrant entrepreneurs is gender. Immigrant women occupy the niches that are less lucrative (Light, 2007). They are "double disadvantaged", first as immigrants and second as women, and, therefore, earn less than males (Kushnirovich, 2007).

Firm characteristics usually include engagement in a certain sector of business activity and duration of business activity. Many scholars stress that immigrant entrepreneurs engage in different business activities than native-born persons do, due to the particularities of their human and cultural capital (differences in education, professions, cultural norms, beliefs, and values derived from the culture of origin). Bates (1985) claimed that educated and more productive ethnic entrepreneurs are concentrated in businesses outside the retail and service industries. Robb and Fairlie (2009), in their study on entrepreneurs of Asian origin in the USA, found that they were less frequently engaged in mining and construction industries than native entrepreneurs were, and were more likely to be found in the wholesale industry, which is characterized by higher capital requirements for entry. Yet, they were about equally likely as "whites" to be in the personal services industry and professional services. Chances of a business to succeed are lower in such industries as retail, accommodation, and food service activities (Riva \& Lucchini, 2015). Correspondingly, industries such as manufacturing and wholesale trade are more successful (Fritsch, Brixy \& Falck, 2006). Different distribution of immigrant and nativeborn entrepreneurs among the industries can be explained by the fact that in less attractive branches low start-up capital is required. Firm's age or experience, expressed as number of years in business, is another important predictor of the income received from the business (Shoobridge, 2006).

\section{MATERIAL AND METHODS}

\section{Model Specifications}

This study transcends Berry's (1997, 2003, 2005) concept and develops its application to integration of entrepreneurs. All immigrant entrepreneurs can be placed on a bidimensional scale based on two basic criteria, which can receive either negative or positive values: economic integration and socio-cultural integration (Figure 1). Keeping in mind that the main aim of a business is generating income for its owners, income received by an entrepreneur from business reflects the entrepreneur's success and represents returns to the entrepreneur on investment in the business (Ndofor \& Priem, 2011). Self-employment earnings differ from salary since they represent not only returns on human capital but also returns on financial capital (Lofstrom, 2011). Thus, income received from a business can be used as a measure of the immigrant entrepreneur's economic success, which is a proxy of economic integration. In this study, economic integration is described in terms of income received by the entrepreneur from a business, and socio-cultural integration is described in terms of host country language skills and length of living in the host country. A model of immigrant entrepreneurs' integration is presented in Figure 1. 


\section{Economic integration of immigrant entrepreneurs}

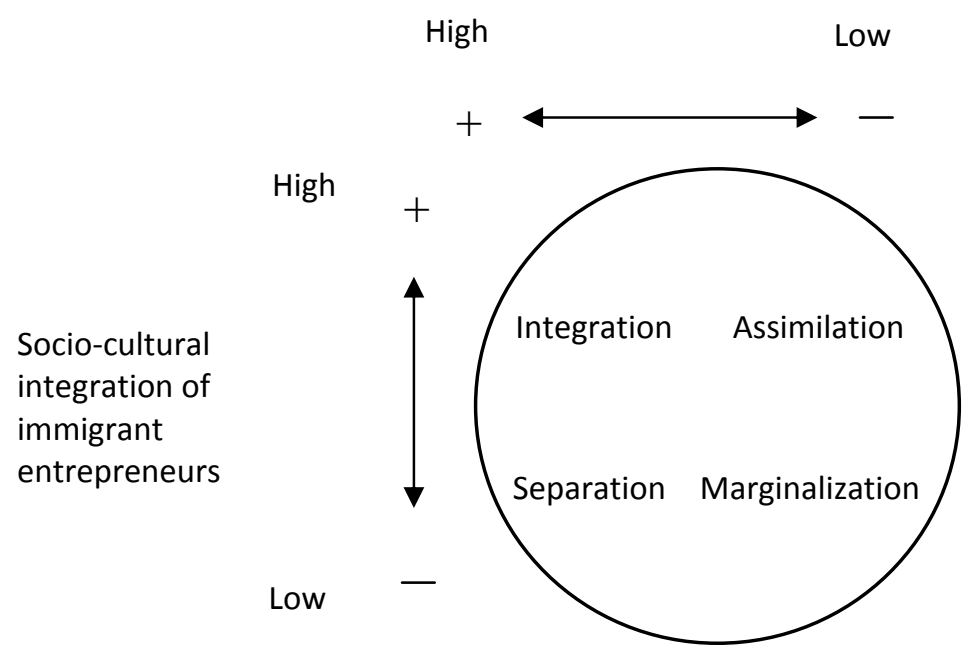

Figure 1. Model of entrepreneurs' integration

Source: own study based on the Berry's model (Berry, 1997, 2003, 2005).

If socio-cultural integration of immigrant entrepreneurs is low (for example, entrepreneurs have lived in the host country for a short time and have low host language skills), and their income is lower than that of native-born entrepreneurs, they can be perceived as marginalized. Those with low socio-cultural integration, but having an income similar to or even higher than that of native businesses, can be considered as separated. They can receive higher income than native entrepreneurs do because they utilize advantages provided by ethnic networks and ethnic-protected markets. The higher the socio-cultural integration of immigrant entrepreneurs is, the more assimilated they are. Nevertheless, their income is low because of specific difficulties and constraints that immigrants face when entering common non-ethnic competitive markets. And finally, immigrant entrepreneurs can be perceived as integrated if they are both socio-culturally and economically integrated: they are proficient in the host country language, and due to their long exposure to the host country have acquired rich social and cultural capital contacting with natives. All that allows immigrants to utilize opportunities of both ethnic and non-ethnic markets, and, due to that, receive an income which is the same or even higher than that of native-born entrepreneurs. It is important to note that economic integration may influence socio-cultural integration as well; economic inclusion can lead to social inclusion and vice versa. Thus, the concepts of socio-cultural and economic integration are interrelated.

Based on the model of entrepreneurs' integration and the literature review, it can be hypothesised that:

H1:

There will be differences in business generated income between native-born and immigrant entrepreneurs of different origin. 
Socio-cultural integration in terms of Hebrew proficiency (H2.a) and length of

H2: living in the host country (H2.b) significantly relates to economic integration of immigrant entrepreneurs.

Effects of socio-cultural integration in terms of Hebrew proficiency (H3.a) and

H3: length of living in the host country (H3.b) will be different for immigrants of different origin.

Income received from a business is used as a measure of an immigrant entrepreneur's economic integration. Since income is an ordinal variable, I used ordered regression model in order to determine whether indicators of socio-cultural integration affect the income and estimate their effects while controlling for a set of personal and business characteristics. The ordered logit model is built around a latent regression, where $Y_{i}^{*}$ is the unobserved dependent variable of income, $X_{i}$ is a vector of explanatory variables, $B$ is an unknown parameter vector, and $\varepsilon$ is the error term:

$$
Y_{i}^{*}=\beta X_{i}+\varepsilon_{i}
$$

Instead of $Y_{i}^{*}$ the following is observed:

$$
\begin{aligned}
& Y=1 \text { if }: \mathrm{Y}^{*}<\mu_{1} \\
& Y=2 \text { if }: \mu_{1} \leq \mathrm{Y}^{*}<\mu_{2} \\
& \vdots \\
& Y=J \text { if }: \mu_{J-1} \leq \mathrm{Y}^{*},
\end{aligned}
$$

where:

$Y$ - is the category of income ranked into jcategories, $\mu$ is the vector unknown threshold parameters estimated with the $B$ vector.

The final model specification for $Y_{i}^{*}$, the gross monthly income derived from a business by an individual $i$, is:

$$
Y_{i}^{*}=\alpha P_{k, i}+\delta Z_{m, i}+\gamma S_{t, i}+\omega \theta_{n, i}+\varepsilon_{i}
$$

In equation (2), $P_{k}$ represents a vector of personal characteristics, such as age, gender, and education; $Z_{m}$ represents a vector of business characteristics, such as duration of business activity and a sector of business activity; $S_{t}$ represents the entrepreneur's socio-cultural integration characteristics, such as Hebrew proficiency and years since migration (YSM); and $\vartheta_{n}$ represents dummies expressing country of origin. The $\varepsilon$ term does not appear to be under the person's control and is associated with unexpected positive and negative circumstances of business activity.

In order to examine whether the effects of integration terms on the entrepreneur's income differ across immigrant entrepreneurs of different origin, a multiplicative interaction regression modelwas conducted. In addition to the main predictors, the model included interactions between dummy variables of origin and variables reflecting the immigrant entrepreneur's integration. The following regression was then estimated:

$$
Y_{i}^{*}=\alpha P_{k, i}+\delta Z_{m, i}+\gamma S_{t, i}+\omega \theta_{n, i}+\rho \theta_{n, i} \times S_{t, i}+\varepsilon_{i}
$$

\section{Data}

This study is based on the data of the annual Social Survey conducted by the Israeli Central Bureau of Statistics. The survey population comprises of the permanent 
non-institutional population of Israel aged $20^{1}$ and older, and immigrants are included in the survey population if they have been present in Israel for at least six months. The Israeli Social Survey does not include temporary workers or non-permanent residents. Since the survey sample is a representative of the Israeli population, of which immigrants constitute only about a quarter, and taking into account that the rates of entrepreneurship of total Israeli population are about fifteen percent, only about 200 immigrant entrepreneurs participate every year in the Social Survey. In order to increase the number of immigrant entrepreneur respondents in the study sample, the data of three annual social surveys conducted in 2008, 2010 and 2012 were combined. Social Survey questionnaires were administered by means of computer-assisted personal interviews that lasted about an hour.

It is important to note that under the Israeli Law of Return, immigration to Israel is selective for Jews and members of their families, who are awarded citizenship upon arrival. Therefore, there are no official visa or financial requirements to become an immigrant entrepreneur in Israel. Despite some similarity in religious and ethnic backgrounds, the differences in the cultural capital according to the countries of origin are still considerable. Based on the origin, immigrants to Israel are traditionally divided to sub-ethnic groups: immigrants from Europe \& America (hereafter E\&A), so called Ashkenazim, and immigrants from Asia-Africa (hereafter A\&A), called Mizrahim or Sephardim. Most Mizrahim immigrated from Muslim countries of Asia and North Africa, and Ashkenazim arrived mostly from Christian countries (Smooha, 2008). Since the mid-1980s, immigration from Ethiopia started. Although Ethiopian immigrants are a distinct subethnic community with their own language and tradition, they are a relatively small group that comprises only about $5 \%$ of all immigrants who came in Israel in this period. In the Israeli national statistics, they are usually included in the A\&A immigrant group. In the 1990s, after the collapse of the Former Soviet Union (hereafter FSU), the massive wave of immigration from FSU states began. FSU immigrants created a separate ethnic sub-group, which is characterized with developed ethnic communities (Horowitz, 2005; Kushnirovich 2007, 2010; Remennick, 2004). FSU immigrants are the largest group of immigrants, which constitutes more than 80 percent of the new immigrants who have entered Israel since 1990, and comprises today more than 10 percent of the Israeli population.

The differences in levels of education, income, and labor market position between immigrants from E\&A, A\&A, and FSU, all favoring the first group, are well-documented (Cohen \& Haberfeld, 2007; Lewin-Epstein \& Semyonov, 1992; Smooha, 2008). A\&A immigrants can be considered as a low-skilled group, and E\&A and FSU immigrants as highskilled groups, when FSU immigrants have been living in Israel for a shorter period of time than the other groups. Another dissimilarity between FSU and other immigrants is that for the latter, the main motives for immigration to Israel were religious, as well as anti-Semitic concerns and lack of personal security, while the motives of FSU immigrants were more diverse and included economic considerations (Amit, 2012). In this study, three groups of immigrants are considered separately. The final sample of the study includes 1709 entrepreneurs: 1133 native-born entrepreneurs and 576 immigrant entre-

\footnotetext{
${ }^{1}$ Due to compulsory military service to which both men and women are obligated, $18-20$ years old persons do not participate in Social Surveys.
} 
preneurs, thereof 194 E\&A entrepreneurs, 208 A\&A entrepreneurs, and 174 FSU entrepreneurs.

Since the study is based on the data deriving from surveys conducted by the Central Statistics Bureau, and the survey questionnaire did not include questions about co-ethnic clients, suppliers, and workers, there was no opportunity to assess the level of co-ethnic business dealing. In this study, socio-economic integration is expressed in terms of language skills and duration of living in the host country. However, one can suppose that entrepreneurs, who reported low Hebrew skills and lived in Israel for a short time, would be inclined to operate in co-ethnic enclaves.

Income generated by an immigrant entrepreneur from a business (in terms of salaries, dividends, etc.) is an ordinal variable categorized on a scale of " 1 " $=2000$ NIS or less per month to " 10 " = more than 21000 NIS per month. Gender is measured by a dummy variable ( 0 = female; $1=$ male). Age is an ordinal variable categorized on a scale of " 1 " to "10" (" 1 "=20-24 years old, "2"=25-29, "3"=30-34, "4"=35-39, "5"=40-44, "6"=45-49, "7"=50-54, "8"=55-59, "9"=60-64, "10"=65-70²). Marital status is indicated by a dichotomy variable ("1" = Married/Living with a partner; "0" = Single/Widowed/Divorced). Years of education are coded on a scale from " 0 " = did not study at all to " 6 " = 16 years or more. Hebrew proficiency is based on three components: speaking Hebrew, writing in Hebrew, and reading in Hebrew, when each is categorized on a scale of " 1 " = no command at all to " 5 " = very good command. The Index of Hebrew proficiency is computed as an average of these three items; their reliability coefficient showed an internal consistency (Cronbach alpha $=0.945$ ). Years since migration are a continuous variable. Duration of business activity is categorized on a scale of " 1 " = 6-11 months to " 11 " = 40 years or more. Business branches are classified on the basis of Social Survey statistical classification of economic activities into: Agriculture, Manufacturing \& Construction (hereafter AMC); Trade, Transport, Storage \& Communication (hereafter TTSC); Renting, Banking, \& Insurance (hereafter RBI); Health Services \& Social Work (hereafter HSW); Education, Community Services \& Social Services (hereafter ECS); Accommodation, Restaurants \& Private Services of Households (hereafter ARP). The year of survey, reflecting macroeconomic situation and other environment factors, was included as a control variable, and measured by dummy variables 2008 and 2010, when the reference category was 2012 . Origin of immigrants was presented as a set of dummy variables: FSU, $A \& A$, whereas immigrants from E\&A were the reference group.

\section{RESULTS AND DISCUSSION}

\section{Characteristics of Entrepreneurs}

The rates of entrepreneurship among immigrants from E\&A and A\&A are almost 1.5 times higher than those of the Israeli-born population: 21.7 percent among immigrants from E\&A, and 20.6 percent among immigrants from A\&A versus 14.4 percent among the Israeli-born population. However, entrepreneurship rates among FSU immigrants are only 7.4 percent, significantly lower than the rates of other population groups (Chisquare=165.8, Sig. $=0.000$ ).

\footnotetext{
${ }^{2}$ In Israel, the work age is up to 67 years for men and 65 years for women.
} 
The demographic characteristics of entrepreneurs differ by their origin (Table 1). The share of women is the highest among immigrant entrepreneurs from E\&A (41.2 percent), and the lowest among entrepreneurs from $A \& A$ (25 percent). Entrepreneurs from $A \& A$ are the oldest; they have lived in Israel the longest time and, correspondingly, have the longest duration of business activity. In contrast, immigrants from the FSU are the youngest among immigrants; they have lived in the host country the least number of years, and have the shortest duration of business activity.

Table 1. Characteristics of the study sample(entrepreneurs in Israel in 2008, 2010, 2012)

\begin{tabular}{|c|c|c|c|c|c|}
\hline \multirow{2}{*}{ Characteristics } & \multicolumn{4}{|c|}{ Origin } & \multirow{2}{*}{$\begin{array}{c}\text { Test }^{\mathrm{a}} \\
\text { (p-value) }\end{array}$} \\
\hline & Israel & E\&A & A\&A & FSU & \\
\hline Number of entrepreneurs, $\mathrm{N}$ & 1133 & 194 & 208 & 174 & \\
\hline From them: & $100 \%$ & $100 \%$ & $100 \%$ & $100 \%$ & \\
\hline $\begin{array}{l}\text { - Self-employed/ business owner } \\
\text { or receiving payment from cus- } \\
\text { tomers }\end{array}$ & 85.3 & 85.1 & 93.3 & 93.7 & $\begin{array}{l}\text { Chi-square }=17.8^{* *} \\
(0.000)\end{array}$ \\
\hline $\begin{array}{l}\text { - Manager of a limited company } \\
\text { owned or controlled by him/her } \\
\text { (at least } 51 \% \text { control) }\end{array}$ & 14.7 & 14.9 & 6.7 & 6.3 & \\
\hline Female, \% & 32.2 & 41.2 & 25.0 & 36.8 & $\begin{array}{l}\text { Chi-square }=13.4^{* *} \\
(0.004)\end{array}$ \\
\hline Age, mean category ${ }^{b}$ & 5.59 & 7.19 & 8.25 & 5.66 & $\begin{array}{l}\text { ANOVA F=91.7*** } \\
(0.000)\end{array}$ \\
\hline Married, \% & 77.2 & 79.4 & 85.1 & 70.1 & $\begin{array}{l}\text { Chi-square }=12.8^{* *} \\
(0.005)\end{array}$ \\
\hline Years of education, mean category ${ }^{b}$ & 5.18 & 5.32 & 4.41 & 5.04 & $\begin{array}{l}\text { ANOVA } \mathrm{F}=37.9 * * * \\
(0.000)\end{array}$ \\
\hline Hebrew proficiency, mean & 4.9 & 4.3 & 4.4 & 3.8 & $\begin{array}{l}\text { ANOVA } \mathrm{F}=204.5^{* * *} \\
(0.000)\end{array}$ \\
\hline $\begin{array}{l}\text { Duration of business activity, mean } \\
\text { category }\end{array}$ & 3.84 & 4.52 & 5.72 & 3.51 & $\begin{array}{l}\text { ANOVA } \mathrm{F}=46.3^{* * *} \\
(0.000)\end{array}$ \\
\hline YSM, mean & & 36.9 & 46.4 & 20.0 & $\begin{array}{l}\text { ANOVA F=160.2*** } \\
(0.000)\end{array}$ \\
\hline Sectors of economy ${ }^{c}$ : & $100 \%$ & $100 \%$ & $100 \%$ & $100 \%$ & $\begin{array}{l}\text { Chi-square }=71.4^{* * *} \\
(0.000)\end{array}$ \\
\hline AMC & 19.3 & 12.6 & 25.1 & 18.0 & \\
\hline TTSC & 21.4 & 18.3 & 31.9 & 20.9 & \\
\hline $\mathrm{RBI}$ & 29.2 & 37.7 & 15.9 & 20.9 & \\
\hline HSW & 8.1 & 14.1 & 6.8 & 13.4 & \\
\hline ECS & 16.3 & 15.2 & 9.7 & 20.9 & \\
\hline ARP & 5.8 & 2.1 & 10.6 & 5.8 & \\
\hline
\end{tabular}

The tests examine the differences between four groups. ***Sig. $<0.000 ; * *$ Sig. $<0.005 ; *$ Sig. $<0.05$.

${ }^{b}$ See description of the variables in Data section.

${ }^{\mathrm{C}} \mathrm{AMC}=$ Agriculture, Manufacturing \& Construction, TTSC $=$ Trade, Transport, Storage \& Communication, RBI = Renting, Banking, \& Insurance, HSW = Health Services \& Social Work, ECS = Education, Community Services \& Social Services, ARP = Accommodation, Restaurants \&Private services of households.

Source: own elaboration based on the data of the Social Surveys conducted by the Israeli Central Bureau of Statistics in 2008, 2010, 2012. 
The groups of entrepreneurs differ as to human endowment. Immigrant entrepreneurs from $E \& A$ are the most educated group, and immigrants from $A \& A$ are the least educated. A high percentage of immigrants from E\&A and Israeli-born entrepreneurs are managers of limited companies owned or controlled by them. In contrast, almost all immigrant entrepreneurs from A\&A and the FSU are self-employed or small business owners (about 93 percent).

Immigrant entrepreneurs from the FSU are the most similar group to Israeli-born entrepreneurs. They resemble their Israeli-born counterparts by gender distribution, age, education, and duration of business activity. They also have similar distribution of businesses by economic sector: like Israeli-born entrepreneurs, they are almost evenly distributed among the AMC, TTSC, RBI, and ECS sectors. However, the distribution of other groups of entrepreneurs differs. Immigrants from E\&A are overrepresented in the RBI sector, and entrepreneurs from A\&A are more likely to be engaged in the TTSC and ARP sectors than other groups of entrepreneurs.

\section{Income of Entrepreneurs by Origin}

The primary question raised in this paper is whether business generated income of immigrants is different from that of native-born entrepreneurs. Table 2 shows nativeimmigrant gaps in estimated incomes of entrepreneurs. Income can be a result of endowments in human capital, a distribution between the sectors of economy, as well as personal characteristics of entrepreneurs. Estimated income is received by means of

Table 2. Native-immigrant gaps in estimated income received from business, by sector of economy (Israel in 2008, 2010, 2012)

\begin{tabular}{|c|c|c|c|c|}
\hline \multirow{2}{*}{ Income from business } & \multicolumn{3}{|c|}{ Income gaps between the groups ${ }^{a}$} & \multirow{2}{*}{$\begin{array}{c}\text { ANOVA } \\
F^{a} \\
\text { (p-value) }\end{array}$} \\
\hline & Israel - E\&A & Israel - A\&A & Israel - FSU & \\
\hline Total & -0.47 & $0.69 *$ & $1.37 * * *$ & $\begin{array}{l}\mathrm{F}=13.776^{* * *} \\
(0.000)\end{array}$ \\
\hline \multicolumn{5}{|l|}{ By sectors of economy } \\
\hline AMC & 1.11 & $1.51 * *$ & 1.18 & $\begin{array}{l}\mathrm{F}=5.317^{* *} \\
(0.001)\end{array}$ \\
\hline TTSC & 0.45 & $1.53 * * *$ & $1.83^{* * *}$ & $\begin{array}{l}\mathrm{F}=8.315^{* * *} \\
(0.000)\end{array}$ \\
\hline RBI & $-1.44 * * *$ & -0.32 & 1.12 & \begin{tabular}{|l|}
$\mathrm{F}=8.011 * * *$ \\
$(0.000)$
\end{tabular} \\
\hline HSW & -0.57 & 0.63 & -0.94 & $\begin{array}{l}F=0.850 \\
(0.468)\end{array}$ \\
\hline ECS & -0.34 & -1.81 & $2.19 * *$ & $\begin{array}{l}F=5.963^{* *} \\
(0.001)\end{array}$ \\
\hline ARP & 1.97 & 1.31 & 0.92 & \begin{tabular}{|l|}
$F=1.030$ \\
$(0.383)$
\end{tabular} \\
\hline
\end{tabular}

asterisks show that the Scheffe test found significant difference in income between native-born entrepreneurs and a certain group of immigrants. Negative gaps show that the income of native-born entrepreneurs is lower than that of immigrants.

$* * *$ Sig. < 0.000; **Sig. < 0.005; *Sig. < 0.05 .

Source: own elaboration based on the data of Social Surveys conducted by the Israeli Central Bureau of Statistics in 2008, 2010, 2012. 
ordinal regressions when regressors were education, age, gender, duration of business activity, engagement in a certain sector of economy, and the year of survey, which reflects the macroeconomic conditions. Estimated income of native-born entrepreneurs was $7.23(S D=3.33)$, of $E \& A$ entrepreneurs was $7.70(S D=3.68)$, of $A \& A$ entrepreneurs was 6.54 ( $S D=2.65)$, and of FSU entrepreneurs was $5.86(S D=2.99)$.

The study found significant differences between entrepreneurs of different origins, but one cannot say that the income of immigrant entrepreneurs is generally low. Whereas the incomes of entrepreneurs from A\&A and FSU are significantly lower than those of their native-born counterparts are, immigrants from E\&A receive equal and in some sectors even higher income than that of Israeli-born entrepreneurs, after controlling for personal and business characteristics. Entrepreneurs from FSU, on average, receive the lowest income. Thus, the first hypothesis, that there are differences in income between native-born and immigrant entrepreneurs of a different origin, is supported.

Although the levels of income vary among the groups, the differences by sectors are less markable. All entrepreneurs engaged in the HSW and ARP sectors had similar income irrespective of their origin. In other sectors, significant differences were found only for certain groups. For example, in the ECS sector, the only difference was between FSU and Israeli-born entrepreneurs, and in the AMC sector, the only significant difference was between $A \& A$ immigrants and native entrepreneurs. It seems that the differences in business income can be explained by different engagement in economic sectors rather than by the fact of being an immigrant.

\section{Effect of Socio-Cultural Integration on Economic Integration}

One of the questions raised in this paper was how socio-cultural integration with the host society affects economic integration of immigrant entrepreneurs; and what the differences in its effect between immigrants of different origin are. Socio-cultural integration of entrepreneurs is described in terms of length of residence in the host country (YSM) and Hebrew skills. Effects of these factors on income are examined by means of ordinal regression analysis pooled across groups of immigrant entrepreneurs, when personal characteristics of entrepreneurs were controlled (Model 1 in Table 3). Gender was found to have a significant effect on income of entrepreneurs, indicating that male immigrant entrepreneurs have higher income that their female counterparts. The analysis revealed positive relationships between education and income, and a negative relationship between age and income. The absence of significant effect of the year of survey on the dependent variable supports merging data of surveys conducted in three different years. Business activity in the HSW sector is positively associated with income, and business activity in ARP is negatively associated.

The level of Hebrew proficiency positively affects income even after controlling for entrepreneurs' characteristics and origin. However, no significant relationship was found between income and YSM, or income and origin. Thus, hypothesis H2.a, that sociocultural integration in terms of Hebrew proficiency significantly relates to economic integration of immigrant entrepreneurs, is supported. And hypothesis H2.b, that length of the living time in the host country significantly relates to economic integration, is not supported. 
Table 3. Ordinal regressions for determinants of income (Dependent variable: income received from business)

\begin{tabular}{|c|c|c|c|c|}
\hline \multirow[t]{2}{*}{ Variables } & \multicolumn{2}{|c|}{$\begin{array}{l}\text { Model 1: Immigrant } \\
\text { entrepreneurs, } N=576\end{array}$} & \multicolumn{2}{|c|}{$\begin{array}{l}\text { Model 2: Immigrant } \\
\text { entrepreneurs with } \\
\text { interactions, } N=576\end{array}$} \\
\hline & Est. & Wald $^{\mathrm{a}}$ & Est. & Wald $^{\mathrm{a}}$ \\
\hline Threshold [Income = 1] & -.741 & 1.143 & 1.127 & 1.467 \\
\hline Threshold [Income = 2] & -.201 & .085 & 1.665 & $3.215^{*}$ \\
\hline Threshold [Income = 3] & .300 & .191 & 2.163 & $5.428^{*}$ \\
\hline Threshold [Income = 4] & .912 & 1.769 & 2.775 & $8.907 * *$ \\
\hline Threshold [Income = 5] & 1.382 & $4.046^{*}$ & 3.250 & $12.145^{* * *}$ \\
\hline Threshold [Income = 6] & 1.845 & $7.168^{* *}$ & 3.718 & $15.786 * * *$ \\
\hline Threshold [Income = 7] & 2.511 & $13.121 * * *$ & 4.391 & $21.746 * * *$ \\
\hline Threshold [Income = 8] & 3.244 & $21.541 * * *$ & 5.129 & $29.238 * * *$ \\
\hline Threshold [Income = 9] & 4.105 & $33.653 * * *$ & 5.996 & $39.193 * * *$ \\
\hline Gender (Male = "1") & 1.166 & $33.635^{* * *}$ & 1.175 & $33.713 * * *$ \\
\hline Age & -.115 & $3.914 *$ & -.110 & $3.528^{*}$ \\
\hline Education & .318 & $13.333^{* * *}$ & .305 & $12.068 * *$ \\
\hline Duration of business activity & .072 & 2.998 & .073 & 3.024 \\
\hline Hebrew proficiency & .223 & $3.561^{*}$ & .479 & $5.188^{*}$ \\
\hline YSM & .010 & .889 & .001 & .000 \\
\hline \multicolumn{5}{|c|}{ Year of survey: (Reference category: 2012) } \\
\hline 2008 & -.429 & 2.215 & -.401 & 2.655 \\
\hline 2010 & .002 & .000 & .005 & .001 \\
\hline Origin (Reference group E\&A): A\&A & -.318 & 1.734 & .509 & .237 \\
\hline FSU & -.078 & .134 & .833 & .812 \\
\hline \multicolumn{5}{|c|}{ Sector of economy (Reference category AMC): } \\
\hline TTSC & .090 & .115 & .036 & .018 \\
\hline RBI & .553 & $3.957^{*}$ & .508 & 3.289 \\
\hline HSW & 1.266 & $13.427^{* * *}$ & 1.249 & $12.847^{* * *}$ \\
\hline ECS & .003 & .000 & -.010 & .001 \\
\hline ARP & -1.038 & $6.932 * *$ & -1.018 & $6.561 * *$ \\
\hline Hebrew proficiency * A\&A & & & -.156 & .346 \\
\hline Hebrew proficiency* FSU & & & -.481 & 3.695* \\
\hline YSM * A\&A & & & .003 & .053 \\
\hline YSM *FSU & & & .034 & $3.142^{*}$ \\
\hline Pseudo R-Square & 0.249 & & 25.7 & \\
\hline Chi-Square & $131.848 * * *$ & & $137.048 * * *$ & \\
\hline
\end{tabular}

a ***Sig. < 0.000; **Sig. < 0.005; *Sig. $<0.05$.

Source: Elaboration based on the data of Social Surveys conducted by the Israeli Central Bureau of Statistics in 2008, 2010, 2012.

The next question was whether effects of socio-cultural integration in terms of length of residence in the host country and Hebrew proficiency are different among immigrants of different origin. In order to examine this, the interactions between group variables and variables describing socio-cultural integration were added (interaction regression Model 2 in Table 3). In Model 2, the effects of gender, age, education, Hebrew proficiency, and sector of economy remain statistically significant. There were no signifi- 
cant effects of interactions with A\&A origin, but interactions with FSU origin were significant. This means that the effects of Hebrew proficiency and YSM on business income are rather similar for immigrants from $A \& A$ and $E \& A$, but significantly different for FSU immigrants. Among FSU immigrants, the effect of YSM on income is positive and significantly higher than that for immigrants of other origin. For immigrants from $A \& A$ and $E \& A$, effects of Hebrew proficiency are positive and significant. However, for immigrants from FSU, the effect of Hebrew proficiency is significantly lower and almost equal to zero. Thus, Hebrew proficiency does not affect business income of FSU immigrant entrepreneurs. Thus, hypothesis H3 that the effects of socio-cultural integration in terms of Hebrew proficiency(H3.a) and YSM (H3.b) will be different for immigrants of different origin is supported only for FSU immigrants. Effects for immigrant entrepreneurs from E\&A and $A \& A$ are rather similar.

\section{CONCLUSIONS}

This study investigated economic integration of immigrant entrepreneurs in terms of their incomes, testing whether socio-cultural integration relates to economic integration of immigrant entrepreneurs. The study found that being an immigrant does not mean automatically receiving lower income. Certain groups of immigrant entrepreneurs (immigrants from E\&A) receive income that is even higher than that of native-born entrepreneurs, while immigrants of other origins receive similar or lower income. Economic integration means that the immigrant entrepreneurs' income would not be lower than that of native-born entrepreneurs when other observable individual, business, and macroeconomic factors are equal. E\&A immigrants demonstrate the highest economic integration. The economic integration of $A \& A$ immigrant entrepreneurs is relatively low since their income is lower than that of native-born entrepreneurs, and FSU immigrants are the least economically integrated group of entrepreneurs.

According to the developed typology of entrepreneurs' integration, the combination of socio-cultural and economic integration describes the strategy adopted by immigrants. Since the economic integration of E\&A immigrant entrepreneurs is high, and their socio-cultural integration (in terms of language proficiency and YSM) is also high, they adopt an integration strategy. A\&A immigrant entrepreneurs are characterized by low economic integration and high socio-cultural integration (high Hebrew abilities, as well as long exposure to the host country); thus, they assume a separation strategy. Since FSU immigrant entrepreneurs demonstrate low levels of both socio-cultural and economic integration, it can be concluded that they adopt marginalization strategy. This finding is consistent with previous studies on FSU immigrants in Israel, which stressed that FSU immigrants are inclined to maintain and even cherish the culture and identity of their origin (Horowitz, 2005; Kushnirovich 2007, 2010; Remennick, 2004). The important conclusion of this study is that socio-cultural integration is not necessarily associated with economic integration. Immigrants can be integrated socio-culturally yet still earn less than their native-born counterparts do. It seems that the choice of a strategy of integration depends on the origin of the immigrants. Further studies are needed in this field.

The second conclusion is that immigrants' socio-cultural integration works in a different way within immigrant groups. For FSU immigrant entrepreneurs, Hebrew proficiency contributes significantly less, and length of living in the host country contributes 
significantly more to income than for the other groups of immigrants. This can be explained by the theory of co-ethnic dealing, according to which immigrant entrepreneurs tend to engage in co-ethnic business activity. Entrepreneurs acting within ethnic niches do not have to be very proficient with the host country language. Moreover, dealing within co-ethnic communities and utilizing co-ethnic networks can contribute to the entrepreneurs' income, giving them some advantages in the market of the host society. As was mentioned in the literature review chapter, previous studies found that immigrants from the FSU are likely to set up ethnic businesses, which explains why Hebrew proficiency does not increase their income (Lerner \& Khavul, 2003; Heilbrunn \& Kushnirovich, 2008). Since the surveys data did not include information about co-ethnic dealing, future studies should examine the relationship between co-ethnic dealing and economic integration.

Differences in the effect of length of residence in the host country can be explained by the accumulated effect of living in the host country. The first years after immigration are very important for the immigrant's integration and significantly contribute to his/her familiarity with the market and business environment of the host country. The marginal effect of these first years on income can be critical. However, with the years, when the immigrant is already familiar with the business "game rules" in the host country, the marginal effect of years should gradually decrease and come to naught. Since FSU immigrants came later and their duration of living in Israel is shorter, the marginal effect of years since migration for this population should be larger.

The interesting finding is that different determinants have similar impact on the income of immigrant entrepreneurs from E\&A and immigrants from $A \& A$. This is in spite of the fact that immigrant entrepreneurs from E\&A are the most educated, and immigrants from Asia \& Africa are the lowest educated. The study found only minor differences in income between entrepreneurs from E\&A and immigrants from $A \& A$, when according to the national Israeli statistics these differences do exist for salaried workers: the income of salaried workers from A\&A is significantly lower than that of workers from E\&A. This means that entrepreneurship can be a viable solution to decrease income inequality, especially for low-skilled immigrants.

This study provides some policy implications. Understanding integration of immigrant entrepreneurs and the factors affecting their income will help policy-makers facilitate their economic advancement. The question how entrepreneurs' socio-cultural integration affects their economic integration is of the greatest practical importance. A few decades ago, the concept of assimilation (the so-called 'melting pot') prevailed in the policy of most host countries. However, with the rise of cultural pluralism and acceptance of multiculturalism, the concept of integration became more widespread. This study revealed that socio-cultural integration is not necessarily accompanied by economic integration and vice versa. The findings support an integrationist orientation of immigrant policy.

This study has some limitations. The first concern is that it examined only on-going ventures and did not regard failed ones. Another concern of the study is that the sample size is quite small for certain groups. Since the study is based on the data of surveys conducted by the Central Statistics Bureau, which did not include questions about co-ethnic business networks, there was no opportunity to assess the level of co-ethnic business 
dealing. The last limitation is a possible two-way relationship between socio-cultural and economic integration. Speaking Hebrew well helps to achieve a better income, but receiving a higher income allows immigrants to socialize more outside their ethnic enclave. These limitations must remain a consideration when generalizing this study's findings.

\section{REFERENCES}

Aguilera, M. B. (2009). Ethnic enclaves and the earnings of self-employed Latinos. Small Business Economics, 33(4), 413-425.

Algan, Y., Dustmann, C., Glitz, A., \& Manning, A. (2010). The economic situation of first and second-generation immigrants in France, Germany and the United Kingdom. The Economic Journal, 120(542), F4-F30.

Amit, K. (2012). Social integration and identity of immigrants from western countries, the FSU and Ethiopia in Israel. Ethnic and Racial Studies, 35(7), 1287-1310.

Barrett, G., Jones, T., McEvoy, D. \& McGoldrick C. (2002). The economic embeddedness of immigrant enterprise in Britain. International Journal of Entrepreneurial Behaviour and Research, 8 (1), 11-31.

Bates, T. (1985). Entrepreneur human capital endowments andminority business viability. The Journal of Human Resources, 20(4), 540-554.

Bates, T. (1996). Determinants of survival and profitability among Asian immigrant-owned small businesses. In H. Duleep \& P. Wunnava (Eds.), Immigrants and Immigration Policy. Greenwich, Connecticut: JAI Press.

Baycan-Levent, T. \& Nijkamp, P. (2009). Characteristics of migrant entrepreneurship in Europe. Entrepreneurship and regional development, 21(4), 375-397.

Berry, J.W. (1997). Immigration, acculturation, and adaptation. Applied Psychology: An International Review, 46 (1), 5-68.

Berry, J. W. (2003). Conceptual approaches to acculturation. In K. M. Chun, P. B. Organista, \& G. Marin (Eds.), Acculturation: Advances in theory, measurement, and applied research, (pp. 1737). Washington: American Psychological Association.

Berry, J. W. (2005). Acculturation: Living successfully in two cultures. International Journal of Intercultural Relations, 29(6), 697-712.

Bommes, M. \& Kolb, H. (2006). Migrants' work, entrepreneurship and economic integration. The Dynamics of International Migration and Settlement in Europe. A State of Art, Amesterdão, AUP, 99-132.

Borjas, G. J. (1994). The economics of immigration. Journal of Economic Literature, 32(4), 16671717.

Chiswick, B. R. (1978). The effect of Americanization on the earnings of foreign-born men. Journal of Political Economy, 86(5), 897-922.

Chiswick, B. R., \& Repetto, G. (2000). Immigrant adjustment in Israel: literacy and fluency in Hebrew and earnings. IZA discussion paper 177.

Cohen, Y. \& Haberfeld, Y. (2007). Self-selection and earnings assimilation: immigrants from the former Soviet Union in Israel and the United States, Demography, 44(3), 649-668.

Constant, A., Gataullina, L., \& Zimmermann,K. (2009). Ethnosizing immigrants.Journal of Economic Behavior and Organization, 69(3), 274-287. 
Constant, A., \& Shachmurove, Y. (2006). Entrepreneurial ventures and wage differentials between Germans and immigrants. International Journal of Manpower, 27(3), 208-229.

Constant, A., \& Schultz-Nielsen, M. L. (2004). Immigrant self-employment and economic performance. In T. Tranæs and K.F. Zimmermann (Eds.), Migrants, work, and the welfare state (pp. 213-243). Odense: University Press of Southern Denmark.

Constant, A., \& Zimmermann, K. F. (2006). The making of entrepreneurs in Germany: Are native men and immigrants alike? Small Business Economics,26(3), 279-300.

Constant, A. F., \& Zimmermann, K. F. (2009). Migration, ethnicity and economic integration. IZA Discussion Papers 4620.

Curci, R., \& Mackoy, R. (2010). Immigrant business enterprises: A classification framework conceptualization and test. Thunderbird International Business Review, 52(2), 107-121.

Danes, S. M., Lee, J., Stafford, K., \& Heck, R. K. Z. (2008). The effects of ethnicity, families and culture on entrepreneurial experience: An extension of sustainable family business theory. Journal of Developmental Entrepreneurship, 13(03), 229-268.

Dustmann, C. (2000). Temporary migration and economic assimilation. Swedish Economic Policy Review, 7, 213-244.

Dyer, W.G. (2006). Examining the "family effect" on firm performance. Family Business Review, 19, 253-273.

Ensign, P.C., \& Robinson, N.P. (2011). Entrepreneurs because they are immigrants or immigrants because they are entrepreneurs? A critical examination of the relationship between the newcomers and the establishment. Journal of Entrepreneurship, 20(1), 33-53.

Fairlie, R. W. (2004). Earnings growth among less-educated business owners. Industrial Relations, 43(3), 634-659.

Fritsch, M., Brixy, U. \& Falck, O. (2006). The effect of industry, region, and time on new business survival - A multi-dimensional analysis." Review of Industrial Organiation, 28 (3), 285-306.

Heilbrunn, S., \& Kushnirovich, N. (2007). Immigrant and indigenous enterprises: similarities and differences. International Journal of Business Performance Management, 9(3), $344-361$.

Heilbrunn, S., \& Kushnirovich, N. (2008). Impact of ethnicity on financing of immigrant businesses. International Journal of Business and Globalization, 2(2), 146-159.

Horowitz, T. (2005). The integration of immigrants from the former Soviet Union. Israel Affairs, 11(1), 117-136.

Ibrahim, G., \& Galt, V. (2011). Explaining ethnic entrepreneurship: an evolutionary economics approach. International Business Review, 20(6), 607-613.

Kloosterman, R., \& Rath, J. (2001). Immigrant entrepreneurs in advanced economies: mixed embeddedness further explored. Journal of Ethnic and Migration Studies, 27(2), 189-202.

Kushnirovich, N. (2007). Immigrant women's entrepreneurship. Sociological Papers, 12, 103 - 117.

Kushnirovich, N. (2010). Ethnic niches and immigrants' integration. International Journal of Sociology and Social Policy, 30(7/8), 412-426.

Lerner, M., \& Khavul, S. (2003). Beating the odds in immigrant entrepreneurship: How does founder human capital compare to institutional capital in improving the survival of immigrant owned businesses? Working Paper No. 4/2003. Massachusetts: Babson College.

Lewin-Epstein, N., \& Semyonov, M. (1992). Local labor markets, ethnic segregation, and income inequality. Social Forces, 70(4), 1101-1119.

Light, I. (2007). Women's economic niches and earnings inferiority: The view from the ethnic economy. Journal of Ethnic \& Migration Studies, 33(4), 541-557. 
Lofstrom, M. (2004). Labor market assimilation and the self-employment decision of immigrant entrepreneurs. IZA Discussion Paper 54.

Lofstrom, M. (2011). Low-skilled immigrant entrepreneurship. Review of Economics of the Household, 9(1), 25-44.

Neville, F., Orser, B., Riding, A., \& Jung, O. (2014). Do young firms owned by recent immigrants outperform other young firms? Journal of Business Venturing, 29(1), 55-71.

Ndofor, H. A., \& Priem, R. L. (2011). Immigrant entrepreneurs, the ethnic enclave strategy, and venture performance. Journal of Management, 37(3), 790-818.

Olson, P.D., Zuiker, V.S., \& Montalto, C.P. (2000). Self-employed Hispanics and Hispanic wage earners: Differences in earnings. Hispanic Journal of Behavioral Sciences, 22(1), 114-130.

Portes, A., \& Jensen, L. (1992). Disproving the Enclave Hypothesis: Reply. American Sociological Review, 57(3), 418-420.

Remennick, L. (2004). Language acquisition, ethnicity and social integration among former Soviet immigrants of the 1990s in Israel. Ethnic and Racial Studies, 27(3), 431-454.

Riva, E., \& Lucchini, M. (2015). The Effect of the Country of Birth of the Owner on Business Survival. Evidence from Milan Metropolitan Area, Italy. Journal of Ethnic and Migration Studies, (aheadof-print), 1-21.

Robb, A. M., \& Fairlie, R. W. (2009). Determinants of business success: an examination of Asianowned businesses in the USA. Journal of Population Economics, 22(4), 827-858.

Robinson, P. B. \& Sexton, E. A. (1994). The effect of education and experience on self-employment success. Journal of Business Venturing, 9, 141-156.

Sanders, J. M., \& Nee, V. (1992). Problems in Resolving the Enclave Economy Debate. American Sociological Review, 57(3), 415-418.

Santarelli, E., \& Vivarelli, M. (2007). Entrepreneurship and the process of firms' entry, survival and growth. Industrial and Corporate Change, 16(3), 455-488.

Shoobridge, G. E. (2006). Multi-ethnic workforce and business performance: Review and synthesis of the empirical literature. Human Resource Development Review, 5(1), 92-137.

Smooha, S. (2008). The mass immigrations to Israel: A comparison of the failure of the Mizrahi immigrants of the 1950s with the success of the Russian immigrants of the 1990s. Journal of Israeli History, 27(1), 1-27.

Stone, I., \& Stubbs, C. (2007). Enterprising expatriates: lifestyle migration and entrepreneurship in rural southern Europe. Entrepreneurship and Regional Development, 19(5), 433-450.

Storey, D. J. (1994). Understanding the small business sector. London: Routledge.

Wilson, K. L., \& Martin, W. A. (1982). Ethnic Enclaves: A Comparison of the Cuban and Black Economies in Miami. American Journal of Sociology, 88(1), 135-160. 


\section{Author}

\section{Nonna Kushnirovich}

Ph.D. in Economics. Nonna is a Senior Lecturer at the Department of Economics and Management and a Head of the Economic Studies for Non-Economists at the School of Economics and Business Administration, Ruppin Academic Center (Israel). She is also a Researcher at the Institute of Immigration and Social Integration (Israel). In 2010 Nonna was included in the list of 100 Outstanding Immigrant Scientists in Israel. Nonna Kushnirovich is an Editor in Chief of the Yearbook on Immigration in Israel. Her current research interests include economic aspects of immigration, immigrant entrepreneurship and labor migration.

\section{Correspondence to:}

Nonna Kushnirovich

Department of Economics and Management

Institute for Immigration and Social Integration

Ruppin Academic Center

Emek Hefer 40250 Israel

nonna@ruppin.ac.il

\section{Copyright and License}

This article is published under the terms of the Creative Commons Attribution - NonCommercial - NoDerivs (CC BY-NC-ND 3.0) License http://creativecommons.org/licenses/by-nc-nd/3.0/ 